\section{Sporothrix spp. in Chile}

Rodrigo Cruz Choappa*, Laura Carvajal and Peggy Vieille

Laboratorio de Micología, Universidad de Valparaíso, Chile

Sporotrichosis is an infection caused by a dimorphic fungus belonging to S. schenckii complex [1], is considered an occupational disease, since it affects mainly gardeners or any people with a puncture wound or animal bite [1,2]. In Chile sporothrichosis is a very infrequent disease unlike most countries of Latin America, and its form of presentation is almost exclusively lymphocutaneous in limbs $[3,4]$.

Taxonomic reports have demonstrated that the complex include $S$. schenckii sensu stricto, S. brasiliensis, S. globosa and S. luriei (clinical clade) [6]. Additionally other species; S. mexicana, S. pallida, and $S$. chilensis, have been occasionally associated to infections in humans (environmental clade) $[1,5,6]$. They show different virulence and clinical presentation. S. schenckii sensu stricto and S. brasiliensis can cause cutaneous and deep injury; instead S. globosa that has been described mainly at lymphocutaneous infections (3), and $S$. pallid that has been described in one case of keratitis [7].

\section{Publication History:}

Received: March 23, 2018

Accepted: June 07, 2018

Published: June 09, 2018

\section{Keywords:}

Sporotrichosis, Chile, Morphophysiology, Virulence studies, Environment

In 2012 for the first time in Chile, Cruz et al. identified S. globosa in a female elderly patient, attended by lymphocutaneous sporotrichosis in her upper limb [3]. Later, Rodriguez et al. identified a new specie, $S$. chilensis, from onychomycosis as well as environment.

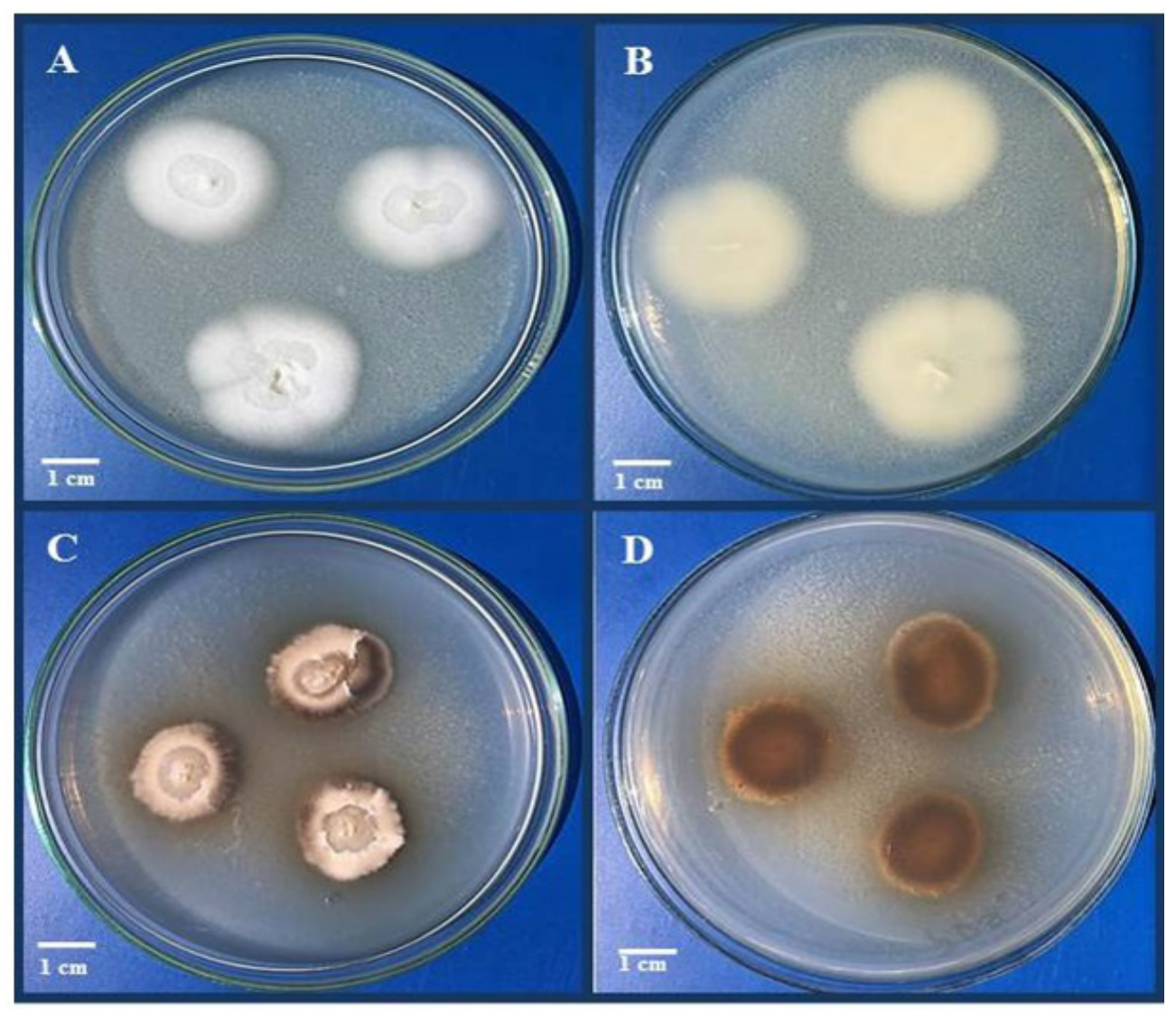

Figure 1:(PDA, $30^{\circ} \mathrm{C}, 21$ days ofincubation). A,B:S. Chilensis.C,D:S. globosa. Laboratorio de Micologia Unversidadde Valparaiso

For the year 2011 sporotrichosis cases published in Chile just began to include the identification of the species [5,8,9], however, it has to be considered that only in 2007 Marimon et al. proposed a morphophysiologic key to differentiate clinically relevant species of the complex, the basis of the key was: conidia pigmentation, grow at different range of temperature on PDA (potato-dextrose agar), and sugar assimilation [1].
*Corresponding Author: Dr. Rodrigo Cruz Choappa, Laboratorio de Micología Universidad de Valparaíso, Hontaneda 2653 Valparaíso, Chile; E-milia; E-mail: rodrigo.cruz@uv.cl

Citation: Choappa RC, Carvajal L, Vieille P (2018) Sporothrix spp. in Chile. Int J Clin Med Microbiol 3: 132. doi: https://doi.org/10.15344/2456-4028/2018/132

Copyright: (C) 2018 Choappa et al. This is an open-access article distributed under the terms of the Creative Commons Attribution License, which permits unrestricted use, distribution, and reproduction in any medium, provided the original author and source are credited. 


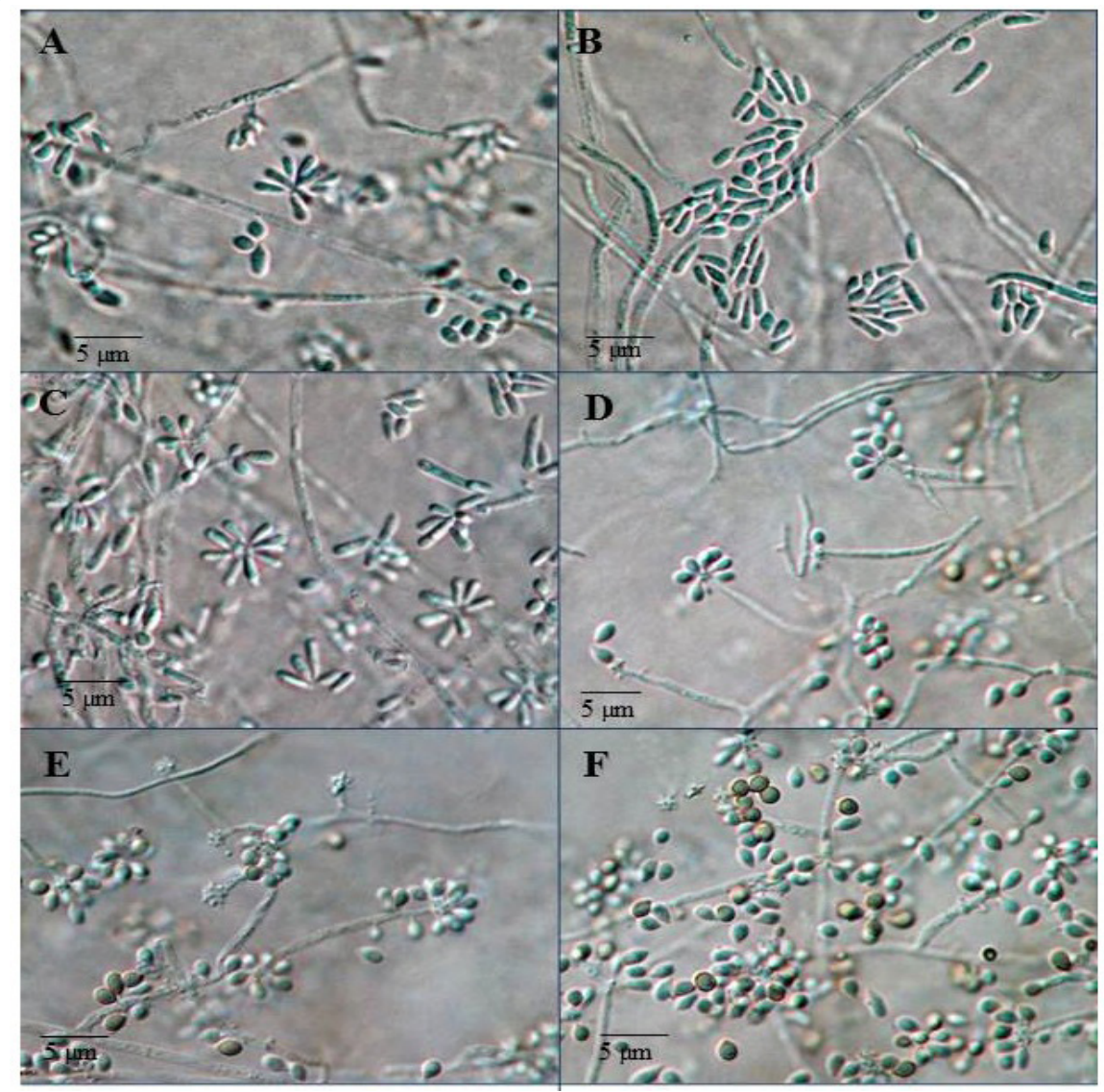

Figure 2: A, B and C: S. chilensi, hyaline obovoid conida, sympodial growth. D, E and F: S. globosa, hyaline primary conidia, and secondary pigmented conidia. Laboratorio de Micologia Unversidad de Valparaiso.

Morphophysiological features of S. globosa incubated at $30^{\circ} \mathrm{C}$ in PDA for 21 days are [1]: colonies growing up to $35 \mathrm{~mm}$ of diameter, becoming cream coloured until second week, then turn to dark (Figure 1). Microscopic characteristic during the first week are thin branched hyphae, hyaline and septate with abundant hyaline conidia in several clusters towards the apex of the conidiogenous cell. Globose to sub globose primary conidia shows sympodial proliferation, 2-5 x 1-3 $\mu \mathrm{m}$ (Figure 2). After second week of incubation, secondary pigmented conidia occur, globose to sub globose 2.5-4 x 2-3.5 $\mu \mathrm{m}$.

S. chilensis features in PDA agar at $30^{\circ} \mathrm{C}$ after 21 days of incubation are [5]: Colonies attained a diameter of 66 to $71 \mathrm{~mm}$ (Figure 1), white coloured that remains at time (Figure1). Microscopic characteristic are hyphae hyaline $(1 \mu \mathrm{m})$, conidiogenous cells usually terminal, primary conidia hyaline, obovoidal, $2.5-4.5 \times 1.2-1.9 \mu \mathrm{m}$ (Figure 2). Also sessile conidia emerge from undifferentiated hyphae, usually globose, $1.4-2.4 \times 1.6-2.8 \mu \mathrm{m}$.

Dimorphism was brought about by incubation in brain heart infusion broth at $37^{\circ} \mathrm{C}$. The yeast phase shows single and multiple budding, $2.5-7 \times 2.1-4.5 \mu \mathrm{m}(3,5)$.

Morphophysiology is helpful to an inceptive approach of genus identification, but molecular identification of calmodulin and $\beta$-tubulin genes through gene sequencing is a fundamental tool, since restrict misidentification secondary to a variability in the morphology of some strains $[1,5]$.
Virulence studies in murine models have evidenced that S. globose and $S$. chilensis show lower virulence, that could explain the less incidence of the disease in Chile, and the absent of deep infections [10], unlike other Latin American countries.

Both diagnostic of sporotrichosis and identification of species are challenging points, it compel us to take over the tools, to obtain a suitable diagnostic and appropriate treatment for the patients.

\section{Competing Interests}

The authors declare that they have no competing interests.

\section{References}

1. Marimon R, Cano J, Gené J, Sutton DA, Kawasaki M, et al. (2007) Sporothrix brasiliensis, S. globosa, and S. mexicana, three new Sporothrix species of clinical interest. J Clin Microbiol 45: 3198-3206.

2. López-Romero E, Reyes-Montes M, Pérez-Torres A, Ruiz-Baca E, VillagómezCastro, et al. (2011) Sporothrix schenckii complex and sporotrichosis, an emerging health problem. Future Microbiol 6: 85-102.

3. Cruz R, Vieille P, Oschilewski D (2012) Aislamiento ambiental de Sporothrix globosa en relación a un caso de esporotricosislinfocutánea. RevChilInfectol 29: 401-405

4. Escaffi MJ, Benedetto A, Podlipnik S, Díaz MC, Misad C, et al. (2010) Esporotricosis cutanea: revisión a propósito de un caso contraído en Chile. RevChilDermatol 26: 154-158. 
5. Rodrigues AM, Cruz R, Fernandes GF, de Hoog GS, de Camargo Z, et al. (2015) Sporothrixchilensissp. nov. (Ascomycota: Ophiostomatales), a soilborne agent of human sporotrichosis with mild-pathogenic potential to mammals. Fungal Biol 120: 246-264.

6. Orofino-Costa R, Macedo PM, Rodrigues AM, Bernardes-Engemann AR (2017) Sporotrichosis: an update on epidemiology, etiopathogenesis laboratory and clinical therapeutics. An Bras Dermatol 92: 606-618.

7. Morrison AS, Lockhart SR, Bromley JG, Kim JY, Burd EM, et al. (2013) An environmental Sporothrix as a cause of corneal ulcer. Med Mycol Case Reports 2: 88-90.

8. Flores C, Ferrada L, De la Parra M (1982) Estudio micológico y experimental de un caso de esporotricosis. Bol Micol 1: 39-42.

9. Berner E, Francotte N, Retamal C, Moyano C, Rodríguez G, et al. (1989) Esporotricosis cutáneo-linfática (casos clínicos). Rev Méd Chile 112: 577 581.

10. Cruz R, Pérez S, Rodríguez V, Vieille P, Opazo H, et al. (2016) Virulencia de Sporothrix globosa en modelos murinos. RevArgent Microbiol 48(3): 196 199. 